\title{
WPS5024
}

\author{
Policy Research Working Paper 5024
}

\section{Potential Gains from Capital Flight Repatriation for Sub-Saharan African Countries}

Hippolyte Fofack

Léonce Ndikumana

The World Bank

World Bank Institute

Poverty Reduction and Economic Management Division

August 2009 
Policy Research Working Paper 5024

\begin{abstract}
Despite the recent increase in capital flows to SubSaharan Africa, the region remains largely marginalized in financial globalization and chronically dependent on official development aid. And with the potential decline in the level of official development assistance in a context of global financial crisis, the need to increase domestic resources mobilization as well as non-debt generating external resources is critical now more than ever before. However, the debate on resource mobilization has overlooked an important untapped source of funds consisting of the massive stocks of private wealth stashed in Western financial centers, a substantial part of which left the region in the form of capital flight. This paper argues that the repatriation of flight capital should take a more prominent place in this debate from a moral standpoint and for clear economic reasons. On the moral side, the argument is that a large proportion of the capital flight legitimately belongs to the Africans and therefore must be restituted to the
\end{abstract}

legitimate claimants. The economic argument is that repatriation of flight capital will propel the sub-continent on a higher sustainable growth path while preserving its financial stability and without mortgaging the welfare of its future generations through external borrowing. The analysis in the paper demonstrates quantitatively that the gains from repatriation are large and dominate the expected benefits from other sources such as debt relief. It is estimated that if only a quarter of the stock of capital flight was repatriated to Sub-Saharan Africa, the region would go from trailing to leading other developing regions in terms of domestic investment, thus initiating a 'big-push'-led sustainable long-term economic growth. The paper proposes some strategies for inducing capital flight repatriation, but cautions that the success of this program is contingent on strong political will on the part of African and Western governments and effective coordination and cooperation at the global level.

This paper-a product of the Poverty Reduction and Economic Management Division, World Bank Institute-is part of a larger effort in the department to enhance domestic resource mobilization in support of investment and economic growth in Sub-Saharan Africa. Policy Research Working Papers are also posted on the Web at http://econ.worldbank.org. The author may be contacted at hfofack@worldbank.org.

The Policy Research Working Paper Series disseminates the findings of work in progress to encourage the exchange of ideas about development issues. An objective of the series is to get the findings out quickly, even if the presentations are less than fully polished. The papers carry the names of the authors and should be cited accordingly. The findings, interpretations, and conclusions expressed in this paper are entirely those of the authors. They do not necessarily represent the views of the International Bank for Reconstruction and Development/World Bank and its affiliated organizations, or those of the Executive Directors of the World Bank or the governments they represent. 


\title{
Potential Gains from Capital Flight Repatriation for Sub-Saharan African Countries ${ }^{1}$
}

\author{
Hippolyte Fofack \\ The World Bank \\ and \\ Léonce Ndikumana \\ African Development Bank
}

JEL Classifications: D31, E62, F34, O19, O55

Keywords: Big push, capital flight, capital flight repatriation, debt relief; Africa.

\footnotetext{
*This paper has greatly benefited from comments by Ibi Ajayi, James Boyce, Stephany Griffith-Jones, Roumeen Islam, Victor Murinde, Raj Nallari, Benno Ndulu and Yaw Nyarko. Earlier versions of the paper were presented at the international seminar on the "Growth and Macroeconomic Implication of Capital Flight for Sub-Saharan African Countries" hosted by the South African Reserve Bank in 2007, and at the African Economic Conference jointly organized by the African Development Bank and the United Nations Economic Commission for Africa in Tunisia in 2008. The authors are grateful to participants to these conferences for their valuable comments and suggestions. The authors also thank Kaouther Abderrahim (African Development Bank) and Nihal Bayraktar (World Bank) for excellent research assistance.
} 


\section{Introduction}

In the Handbook of Development Economics, Cardoso and Dornbusch (1989) summarized the challenges of resource mobilization in support of economic growth and development in low-income countries facing debt overhang and plummeting credit ratings as follows: "Commercial banks are unlikely to provide much development finance in years to come. Bond markets, likewise, will be closed for countries with poor debt experience. Efforts to develop private capital flows to debtor countries must therefore, focus on other mechanisms." Decades later, Cardoso \& Dornbusch's assessment and recommendation still hold and could greatly inform the growth process in the post-HIPC Completion Point era in SubSaharan Africa.

In addition to their poor credit ratings, the majority of Highly Indebted Poor Countries in Sub-Saharan Africa face major challenges that are further compounded by the steadily declining level of international development assistance [World Bank (2006)]. ${ }^{2}$ To enhance the impact of debt relief granted under the HIPC initiative, ${ }^{3}$ there is one possible route that is still unexplored, and yet could generate the massive inflows of capital in support of a 'big push' to accelerate growth: the repatriation of flight capital. Indeed, the hundreds of billions of dollars of capital flight from SSA represent a sizable amount of untapped resources with tremendous potential for economic growth and development if repatriated to source countries.

According to most recent estimates, the cumulative stock of capital flight - the voluntary exits of private residents' capital either for a safe haven or for investments made in foreign currency - from Sub-Saharan Africa amounts to USD 606.7 billion over the three decades spanning 1970-2004 [Ndikumana and Boyce (2008)]. ${ }^{4}$ The high level of capital flight poses serious challenges for domestic resources mobilization in support of investment and growth in the Africa. These challenges are even more important because the region is confronted with acute shortage of capital and is increasingly marginalized in the global distribution of private capital flows, which remains heavily skewed and tilted towards OECD and emerging market economies [World Bank (2006)].5 These challenges are also exacerbated by the absence or relatively low level of 'additionality' of resources within the HIPC framework.

The absence of a 'big push' in the form of large capital inflows supporting the expansion of productive investment, and as a complement to the HIPC initiative is a common problem in stabilization programs implemented in most developing countries. In the aftermath of these programs, most countries often lack the resources needed to operate at the level of investment required to attain robust and sustained growth rates; and when capital does come, it is usually in the form of balance of payments support directed toward highly liquid domestic assets and final consumptions, rather than in physical capital

\footnotetext{
${ }^{2}$ In fact, since 2005, official development assistance has been declining steadily, and even took a negative value in net terms, reflecting net capital outflows from developing countries [World Bank (2006)].

${ }^{3}$ Debt reduction granted to the first batch of 18 countries which became eligible to the HIPC Completion Point under the MDRI for concessional lending granted either through the IDA window or the African Development Bank facility is extended over a four decades, spanning the period 2006-2045. For further details see World Bank (2006).

${ }^{4}$ Capital flight is sometimes measured as errors and omissions in the balance of payments and often refers to illicitly acquired resources. However, the estimated cumulative stock cited here is based on an elaborate methodology that is described in detail in Ndikumana and Boyce (2008).

5 The Global Development Finance Report published in 2006, highlighted the increasingly skewed distribution of capital movements at the global level, with the Sub-Saharan African region largely marginalized from the path of global capital flows and receiving the lowest share of FDI.
} 
accumulation [Laban (1991)]. ${ }^{6}$ Yet sustained increases in capital stock are key to welfare improvement and to the success of stabilization programs, in that it increases the tax base and prospects for employment creation, thus mitigating the risks of recurrence of fiscal deficits and macroeconomic imbalances.

In the past a number of scholars have advocated that stabilization programs be accompanied by policy measures to enhance massive reflows of resources in the form of capital repatriation to source countries. While such repatriation schemes may primarily be viewed as an integral part of a 'big push' model, they may also greatly enhance the success of stabilization programs [Dornbusch (1991)]. According to Dornbusch, capital repatriation reduces the likelihood that the government will run against its external constraints and hence be forced to abandon its stabilization plan. In addition, higher levels of investment in the initially noisy period of adjustment could also mitigate the risk of a decline in living standards and therefore broaden the political support base to advance program implementation [Blejer and Ize (1989)].

Capital repatriation schemes have been used successfully to boost domestic investment and growth in a number of countries in Asia and Latin America. One of the most publicized cases is the mobilization of domestic resources through capital repatriation using debt-equity-swaps programs in Chile [Armendariz de Aghion (1991), Laban and Larrain (1998)]. As a result of this program, Chile achieved investment and growth rates in scales unprecedented. Interestingly, advanced economies have also drawn on capital repatriation schemes to spur growth. The launching of a tax amnesty scheme in favor of private foreign asset holders, enabled the government of Italy to recoup 30 billions of US dollars from Swiss banks in 2001 [Watts (2002)]. ${ }^{7}$

In spite of the significant potential of capital flight repatriation for growth and macroeconomic stabilization, the Sub-Saharan African region has not benefited from it. Yet it is the most capital starved region of the world with the highest proportion of its assets held abroad [Collier et al (2001)]. ${ }^{8}$ A substantial share of these assets is held abroad in the form of liquid assets especially as book deposits. The highly liquid nature of these assets makes the expected transaction costs associated with their repatriation relatively low, and effective repatriation highly probable, provided that there is a sufficiently political will and commitment at the global level.

The object of this paper is to investigate the channels through which KF repatriation will benefit African countries in terms of higher economic growth. We emphasize the gains through higher domestic investment. The analysis shows that if only $25 \%$ of the estimated assets held abroad were repatriated to source countries in support of domestic investments, the sub-continent would go from trailing to leading other developing regions in terms of domestic investment. Its ratio of domestic investment to GDP would increase from $18.5 \%$ to $29.6 \%$. Comparatively, $25 \%$ of the stock of capital flight from the 40

\footnotetext{
${ }^{6}$ Empirical evidences have supported the hypothesis of decumulation of productive assets over most of the adjustment era in Sub-Saharan Africa [Easterly (2002)].

7 Similarly, ongoing disputes between the US and Swiss officials involving US citizens who have used Swiss bank-secrecy laws to hide assets and engage in tax evasion may result in a repatriation of a large amount of resources. Already the Swiss Bank UBS has agreed to pay US\$780 million to the US government to avoid prosecution [Barrett (2009)]. ${ }^{8}$ However, these authors associate the flight of capital to portfolio diversification, as primary motives, a variant from the standards determinants of capital flight from Sub-Saharan Africa. Moreover, to the extent that most resources leaving the continent through capital flight channel are in the form of liquid assets rather than securities and equities, the diversification away from risk and security argument may be more robust in explaining the recurrent outflows.
} 
countries in the sample represents more than twice the total volume of debt relief received by this group of countries. Thus, the growth and welfare returns from capital flight repatriation are clearly superior to expected gains under the stand alone HIPC relief, suggesting that a 'big push' in the form of massive reflows of capital could highly complement the HIPC initiative and enhance its success in recipient countries. ${ }^{9}$

\section{Recent Developments in Capital Flows from and to Developing Countries}

Under the impulse of information and communication technology, the process of globalization has contributed to a dramatic increase in the speed and movements of capital at the global level [World Bank (2002, 2006), Fofack (2009)]. Although this surge in capital flows is a rebound following the 1997 East Asian financial crisis, it has been very strong and robust. In particular, since that rebound, capital flows to developing countries have grown unabated at least until the onset of the current global economic crisis.

Capital flows towards developing countries reached a new record high in 2005, a year that a World Bank report refers to as the "landmark year in global development finance" [World Bank (2006)]. According to this report, total net flows (from official and private sources) increased to US $\$ 472$ billion in 2005. However, this statement must have been a brisk assessment because capital flows have grown in crescendo, and achieved an even more impressive level in 2006, when net flows to developing countries reached US $\$ 571$ billion setting yet another record [World Bank (2007a)].

Nevertheless, the new threshold established in 2005 would have been even higher if the distributions of net official and private flows had not followed divergent paths. While net private capital flows continuously increased after the reversal to buoyancy in the financial markets following the global recovery from the Asian financial crisis, net official flows remained on a path of steady decline, taking on negative values in subsequent years, reflecting net capital outflow from developing countries. ${ }^{10}$

The impressive rate of expansion of capital flows is therefore largely the result of net private flows [World Bank (2007a)]. This remarkable increase in net private capital flows particularly reflects the growing scope of foreign direct investment and globalization of financial flows [Kasekende (2001), Moran et al. (2005)]. It is argued that foreign direct investment is becoming an important contributor to economic growth, and that the benefits of financial globalization are increasingly felt in developing countries [IMF (2007), World Bank (2007a)].

While net equity inflows (portfolio and foreign direct investment) continue to account for the lion's share of net private flows (over 60\%), market-based flows from private creditors in the form of bonds or short-term debt are also growing quite rapidly, reflecting the maturation of financial markets and improvement of credit worthiness in a number of developing economies. Recent estimates suggest that capital inflows from market-based debt are growing even more rapidly than equity flows. Since 1998,

\footnotetext{
${ }^{9}$ Indeed, in spite of access to debt relief under the Enhanced HIPC Initiative, debt sustainability indicators have been deteriorating rather rapidly in a number of post-Completion Point countries, a path which is raising the specter of another debt cycle [World Bank (2006)].

10 The negative net official flows reflect a long-term trend of declining official development assistance. At the same time, a growing number of emerging market economies which are accumulating reserves are changing the landscape of international financial architecture [Summers (2006), Fofack (2009)]. In fact over the past few years, the aggregated value of official flows to East Asia and Latin America has been globally negative. For further details, see World Bank (2006).
} 
gross market-based capital flows to developing countries have grown by more than twofold to reach US $\$ 385$ billion in 2005 [World Bank (2006)]. These developments reflect the growing interest of international investors in local-currency bond markets, and reduction of political risks and macroeconomic instability in an increasingly large number of developing countries, particularly in Europe and Central Asia, East Asia and Latin America, the regions which are benefiting the most from the global surge in capital flows and where yields and potential gains from currency appreciation have been the highest.

In the midst of this surge in net private capital flows, the heavily skewed global distribution of net private capital flows to developing countries has persisted. The Europe and Central Asia (ECA) region, East Asia and Pacific (EAP) region and Latin America and the Caribbean (LAC) region continue to enjoy the lion's share of global capital flows to developing countries (Table A1 and Figure 1). While Sub-Saharan Africa leads all developing regions in official flows such as ODA, it continues to trail in terms of private flows. Naturally, this increasingly skewed distribution of global capital flows further marginalizes SubSaharan Africa, a phenomenon compounded by the delayed financial deepening in the sub-region.

SSA's share of global net private capital flows to developing countries declined in the midst of financial globalization and now accounts for just 10\%, against $41 \%$ for the EAP region, and about 35\% for the LAC (Table A1 and Figure 1). Moreover, market-based inflows to SSA were even lower (less than 3\% of total) and the majority of it went to South Africa, which accounts for over 50 percent of gross marketbased capital flows to the region [World Bank (2006)].

Figure 1: Share of net private capital flows by region (\% of total flows to developing countries), 2007*

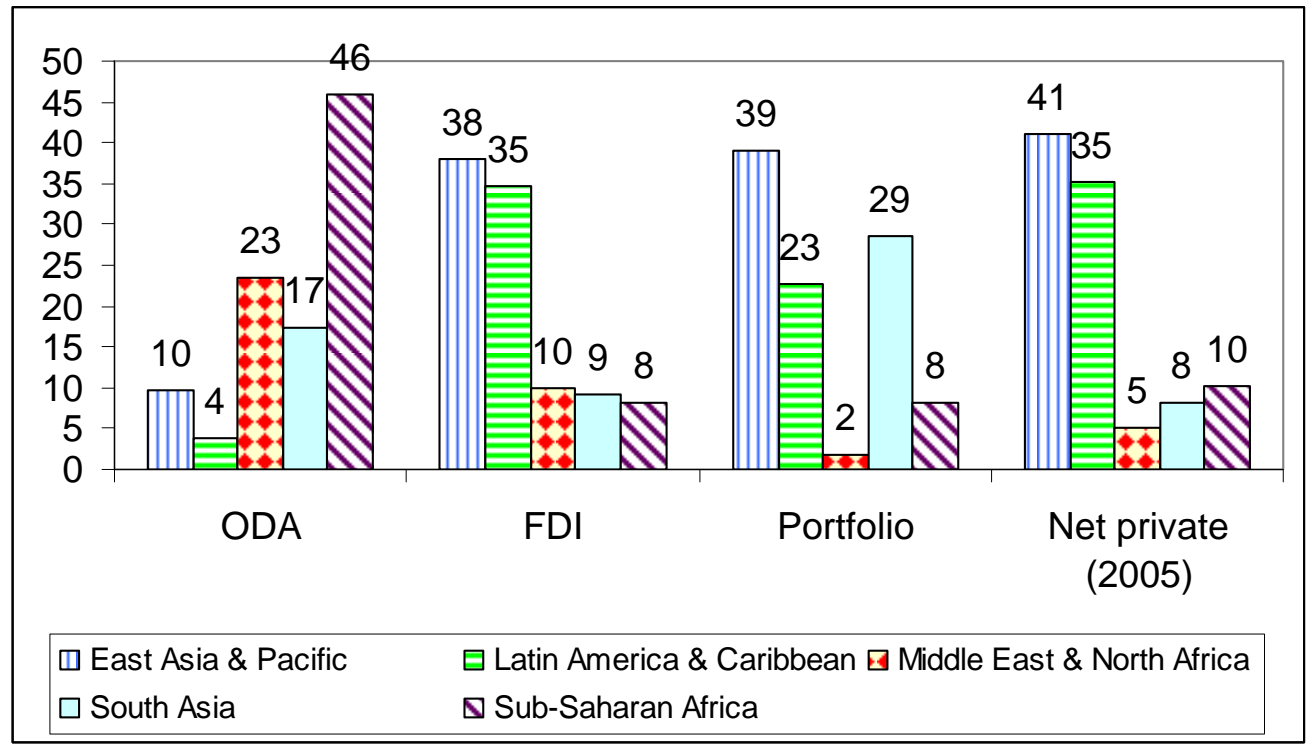

Source: Global Development Finance 2008

* Note: 2005 for net private flows.

The continued strong growth of market-based financial flows reflects the changing pattern of global finance. Equity flows, market-based capital flows and official flows constitute the main forms of capital 
flows to developing countries. ${ }^{11}$ However, while the bulk of the flows to the three largest recipient regions (EAP, ECA and LAC) are primarily driven by investment motives and opportunities, capital flows to SSA are still dominated by official development assistance. FDI to SSA heavily concentrates in natural resources and particularly oil and gas sectors, and has been highly volatile [UNECA (2006)].

However, unlike private flows and particularly FDI, part of the official flows come in the form of balance of payments support, and as such are primarily used to finance current account deficits. In this regard, their prospects for expanding capital expenditures for long-run growth and economic development are likely to be lower. In a number of empirical studies based on a cross-section of countries, Kose et al. (2006) found that non-FDI flows are less conducive to economic growth than FDI. Similarly, a recent IMF survey found that countries with higher shares of FDI in total liabilities experience higher rates of economic growth [IMF (2007)].

In this regard, the continued large inflows of private capital to emerging market economies may largely explain the robust economic growth enjoyed by these countries. These growth effects of private capital inflows further highlight the benefits of this mode of external financing for engendering virtuous circles of long-run economic growth. According to an IMF study, an increase in FDI by 10 percentage points of GDP is associated with an increase in average growth of 0.3 percentage points (IMF 2007). The massive infusion of capital in emerging market economies played a key role in creating and sustaining the "big push' model - to foster growth and employment creation leading to long-run per capita income growth and economic development during adjustment eras [Edwards (1990), Akyuz and Gore (2001)]. ${ }^{12}$

However, while the initial 'big push' primarily relies on FDI inflows, the repatriation of flight capital held abroad by countries' residents later played a key role in sustaining the process of capital infusion to sustain economic growth. This process of capital repatriation has been largely documented in the LAC region where capital flight was significant in scope and magnitude, with estimates of cumulative stock (including interest earnings) in the range of US $\$ 350$ billion by the late 1980s [Lessard and Williamson (1987), Pastor (1989)]. However, in addition to incentives created by the improved macroeconomic environment, the repatriation process was facilitated by the fact that more than 50 percent of flight capital was held abroad in the form of liquid assets [Armendariz de Aghion (1991)].

According to the United Nations' Economic Commission for Latin America and the Caribbean, significant reflows of capital to the region took place in the 1990s when net private capital flows increased by more than sevenfold. Though numerous countries in the region enjoyed the process of capital repatriation, Chile is often cited as the most successful case where massive repatriation of capital was used to finance productive investment. Net capital inflows to Chile increased to US\$3 billion in the early 1990s, from about US $\$ 1$ billion in the 1980s. These repatriation schemes contributed to a rapid

\footnotetext{
${ }^{11}$ Workers remittances are also growing quite rapidly as another form of private resource inflows to developing countries. Most recent estimates suggest that this form of resources flows has increased significantly and now averages over 5 percent of GDP across the developing world. However, Sub-Saharan Africa still has the smallest share compared to other regions. Remittances going to Sub-Saharan Africa increased to nearly USD 20 billion in 2008, up from USD 10 billion in 2005. Despite their steadily growing trend, remittances cannot sustain the 'big push' given the widening financing gaps faced by the continent and also because remittances are primarily directed to finance household final consumption [Ozden and Schiff (2006), UNECA (2006), Gupta et al. (2007)].

${ }^{12}$ In fact while countries in Asia were experiencing investment booms and rapid per capita income growth, Sub-Saharan African countries faced a rapid decline of gross capital formation in the face of falling investment rates and excess depreciation of capital during the adjustment era [Akyuz and Gore (2001), Bayraktar and Fofack (2007)].
} 
increase in FDI inflows to Chile, which received more than 15 percent of private investment flows to Latin America throughout the 1990s [Laban and Larrain (1998)].

The massive inflow of capital to Chile in the 1990s is often attributed to a combination of favorable external and domestic factors such as increasing interest rate differentials with poorly-performing advanced economies and reduction of the country risk premium, especially following its exit from debt overhang and successful macroeconomic stabilization program. However, it is believed that the improvement of credit worthiness and implementation of debt-equity swaps also played a critical role in the Chilean 'big push'.13

According to Edwards (1990), debt-equity swaps emerged as effective instruments for reducing external debt and increasing private capital flows, contributing to over fivefold increase in capital repatriation. ${ }^{14}$ According to the Institute of International Finance, more than 50 percent of foreign direct investment flowing into the LAC region in the late 1980s and 1990s took place under that program.

In contrast, evidence of repatriation of capital flight to Sub-Saharan Africa is very limited. The purchase of divested state-owned enterprises in Uganda using repatriated flight capital, following the liberalization of capital account, may be viewed as a variant of the debt-equity-swaps, albeit on a much smaller scale. Recent estimates suggest that the cumulative stock of flight capital from the region reached the critical threshold of USD 606.7 billion in 2004, this, even as countries were striving to meet the HIPC conditionalities that grant eligibility to debt relief [Ndikumana and Boyce (2008)].

However, in the midst of this rather disappointing record, Nigeria, one of the countries which has suffered tremendously from capital flight over the years successfully recovered half a billion dollar from Swiss banks in 2005 [World Bank (2007b)]. Though marginal-the cumulative stock of flight capital from Nigeria up to 2004 amounts to USD 240.7 billion-, this repatriation of flight capital sets a precedent for other countries. It is occurring at a particularly critical and opportune moment, when the international community (confronted with the increasing costs of corruption and capital flight, most notably illustrated by the persistence of widespread poverty in Sub-Saharan Africa and the widening income gap with the rest of the world) is working towards the establishment of an institutional framework for curbing illicit capital outflows and ensuring the repatriation of past flight capital. ${ }^{15}$

The commitment of the international community to addressing this financial hemorrhage goes back to December 2000 when the UN General Assembly adopted resolution 55/188 in which it called upon

${ }^{13}$ In particular, the implementation of macroeconomic reforms in Chile and reduction of external debt resulted in a significant improvement of credit rating in the early 1990s. Chile reached investment grade risk rating of BBB from S\&P, the highest in Latin America at the time. The rating has since improved, further enhancing prospects for FDI and portfolio investments. By comparison, credit worthiness remains low across Sub-Saharan Africa where most countries are not even rated. The few exceptions are South Africa and Mauritius which enjoy rating comparable to Chile [World Bank (2006)]. Not surprisingly, these two countries have received the bulk of private capital inflows into the region.

14 The debt-equity-swaps refer to a technique initially developed to reduce a country debt burden through the conversion of a debt from a loan into a firm of government equity holding. This technique was widely used in Latin America.

Though Chile aggressively made use of this technique, it was also implemented in Bolivia, Brazil, Mexico, Venezuela and Argentina, resulting in massive inflows of capital.

15 The widening income and welfare gap between SSA and the rest of the developing world is reflected in the divergent performance on the Millennium Development Goals. While most other regions are slated to meet these globally accepted benchmarks, the SSA region is identified as the one region that is farthest from target [Berg and Qureshi (2005), UNECA (2007a, 2007b)]. 
countries to cooperate through the United Nations system by devising ways and means of preventing the illegal transfer of assets and repatriating illegally transferred funds. Following that resolution, asset recovery was identified as a new and complex field of international cooperation during the United Nations Convention against corruption held in 2006. That same year, the International Centre for Asset Recovery (ICAR) was established by the Basel Institute on Governance. And in September 2007, the Stolen Asset Recovery (STAR) initiative was jointly launched by the World Bank and United Nations Office of Drugs and Crime [World Bank (2007b)].

At the same time, the recovery of looted assets and repatriation of capital flight to source countries is marred with a number of challenges. Not the least because the costs associated with capital flight are not uniformly distributed at the global level. The loss of assets in the form of capital flight for source countries in the south is a benefit in terms savings for recipient countries in the West, which have an incentive to resist repatriation to source countries. Historically, countries seeking the return of flight capital or stolen assets have often been confronted with the challenges of obtaining domestic freezing and confiscation orders that are necessary for the enforcement of such judgments. Moreover, most jurisdictions do not allow for the confiscation and return of assets on the basis of a criminal conviction.

However, according to experts from the International Centre for Asset Recovery, the overwhelming majority of capital flight from Sub-Saharan Africa is held abroad in the form of liquid assets, and particularly in the form of holdings of bank deposits and notes. In this regard, the transaction costs associated with the repatriation of these assets should be relatively low. Essentially, repatriation hinge on the political will and the extent of coordination at the international level.

For instance while political commitment played a critical role in the recovery of billions of US dollars to sanction the misconduct of executives involved in the savings-and-loan debacle by the US government, cooperation at the international level enhanced the repatriation of a portion of flight capital to the Philippines in the post-Marcos era. These cases of success at recovering looted assets in advanced and developing countries augur well and could greatly inform the newly established STAR initiative and enhance the repatriation of flight capital in support of the 'big push' model and as a complement to the HIPC initiative in Sub-Saharan Africa. ${ }^{16}$

\section{Analytical Framework: Linkages between Capital Flight, the Government Budget, Investment, and Growth}

We start by describing a simple theoretical model that allows us to identify the channels through which capital flight can affect economic performance in the context of optimization of inter-temporal allocation of resources by private agents. This provides us with some insights on the gains that will accrue from both curbing capital flight and repatriating capital flight. We will especially emphasize the effects through the government budget (revenue and expenditure) and domestic investment through impact of capital repatriation on savings.

From a portfolio choice perspective, capital flight arises as private agents seek to maximize the returns to assets by taking advantage of higher risk-adjusted returns abroad and by evading domestic taxation. As

\footnotetext{
16 These prospects are further enhanced by the international context of global financial crisis which has fostered increased emphasis on global financial governance, most notably illustrated by pressures on traditional safe havens countries to lift bank-secrecy laws, which has abated capital flight and tax evasion.
} 
resources flee the country, economic performance is adversely affected through the direct effects on domestic capital accumulation (lower domestic savings) and through the effects on the government budget. In particular, capital flight directly and indirectly causes higher external borrowing, which depresses domestic investment and economic growth through the debt overhang effects. Conversely a decline in capital flight and capital flight reversal (repatriation) will reduce the need to borrow abroad, raise domestic savings (higher private savings and tax revenue), thus resulting in higher domestic investment and growth. The simple model described below allows us to identify these various channels that link capital flight to economic performance, which in turn shed light on the potential gains from capital flight repatriation or reversal.

We consider that private agents maximize lifetime utility subject to lifetime resources. To simplify the exposition, we reduce the lifetime to two periods, today (at time $t$ ) and tomorrow (at time $t+1$ ). In period t, the agent has an endowment $W$ from which the agent consumes $(C)$ and saves in the form of domestic capital $(K)$ and foreign capital (or capital flight, $F$ ). In the second (and last) period, the agent consumes output produced using the income from domestic and foreign capital. Domestic capital earns a rate of return of $r$ and is taxed at the rate of $\tau$ while capital flight earns a rate of return of $\rho$ and it is not taxed.

The optimization problem is the following:

$$
\begin{aligned}
& \max _{c} U\left(c_{t}, c_{t+1}\right) \\
& \text { subject to: } c_{t}+K_{t}+F_{t}=W_{t} \\
& c_{t+1}=K_{t}(1+r(1-\tau))+F_{t}(1+\rho)
\end{aligned}
$$

The consolidated budget constraint is the following:

$$
c_{t}+\frac{1}{1+r} c_{t+1}=W_{t}+\frac{\rho-r}{1+r} F_{t}-\frac{r \tau}{1+r} K_{t}
$$

Equation (4) implies that return differentials in favor of foreign assets as well as distortionary taxation of domestic assets induce capital flight. Moreover, capital flight is likely to induce more capital flight simply because capital flight raises utility (by causing the budget constraint to shift out).

One additional implication of equation (4) is that exchange rate movements will have larger effects on households that do not have a significant amount of assets abroad. Households holding only domestic assets bear the full costs of the depreciation of the national currency (which, among other things, reduces the domestic rate of return) while households with foreign assets are able to hedge against the risk of currency devaluation.

To motivate the effects of decline capital flight or capital flight repatriation on economic performance, first we consider the effects through the government budget, and then the effects on domestic capital accumulation and long-run growth. The government budget constraint can be represented as follows:

$$
G_{t}+(1+r) B_{t-1}=\tau K_{t}+R_{t}+\Delta B_{t}+\Delta M_{t}
$$

where $G$ is government expenditures in the first period (including transfers), $B$ is government borrowing, $R$ is government revenue from sources other than taxes on domestic assets, and $\Delta M$ is seignorage (money creation). Capital flight affects the government's budget by reducing taxable domestic assets, which forces the government to either borrow (domestically and from abroad, $\Delta B$ ) or resort to money creation $(\Delta M)$. 
Similarly, capital flight reduces domestic investment directly for a given level of initial endowment as evidenced in equation (2), but also indirectly by increasing macroeconomic uncertainty. The model thus can be used to illustrate the phenomena of debt-fueled capital flight and debt-driven capital flight emphasized in Ndikumana and Boyce (2003) and Boyce (1993).

Conversely, the model allows us to track the gains from a decline in capital flight or repatriation of capital flight through government budget. A decline in capital flight or capital flight repatriation will increase taxable domestic assets, which will raise government revenue. Two effects follow with accompanying impact on domestic investment. First, higher tax revenue increases domestic saving, which will results in higher public investment and, consequently, higher total investment. Second, the lower need for borrowing will reduce macroeconomic uncertainty. The two effects will induce higher private investment.

We describe the linkages between capital flight on long-run economic growth using a simple Solow growth model where capital flight is assumed to affect growth by reducing the volume of domestic saving that effectively finance domestic investment and by the fact that capital smuggling reduces effective labor productivity. We assume that the potential saving rate is $S$ and that a fraction $\phi$ of national output is smuggled in the form of capital flight. We also assume that a fraction $\theta$ of effective labor $L$ is spent on capital smuggling. Total saving available for domestic investment is:

$$
S_{t}=(s-\phi) Y_{t}
$$

Domestic output is produced using domestic capital according to the following production technology:

$$
Y_{t}=A\left((1-\theta) L_{t}\right)^{\beta} K_{t}^{1-\beta}
$$

where $\mathrm{A}$ is total productivity (assumed constant). In per-worker terms $(y=Y / L ; k=K / L)$, equation (7) becomes:

$$
y_{t}=A((1-\theta))^{\beta} k_{t}^{1-\beta}=f\left(\theta, k_{t}\right)
$$

Assuming that the population grows at the rate of $n$ and that capital depreciates at the rate of $\delta$, the change in capital stock can be described by the following equation:

$$
\dot{k}_{t}=(s-\theta) f\left(k_{t}, \theta\right)-(n+\delta) k_{t}
$$

In the steady state, the growth rate of capital stock is zero and the steady-state output is obtained as follows:

$$
f^{*}\left(k^{*}, \theta\right)=\frac{(n+\delta) k^{*}}{s-\phi}
$$

Steady-state output increases as the saving rate $(s)$ increases and decreases as capital flight intensity increases (larger $\phi$ and $\theta$ ).

Using the production function specified above, we obtain the growth rate of capital stock as follows:

$$
\gamma_{k}=\dot{k} / k=(s-\phi) A(1-\theta)^{\beta} k^{-\beta}-(n+\delta)
$$

Equation (11) shows that the growth rate of capital stock - thus the growth rate of output - declines when capital flight increases via an increase in the fraction of output smuggled $(\phi)$ and an increase in the fraction of effective labor spent on capital smuggling $(\theta)$.

The steady-state level of capital stock is given by: 


$$
k^{*}=[A(s-\phi)(1-\theta) /(n+\delta)]^{1 / \beta}
$$

Equation (12) implies that $\phi$ and $\theta$ have a negative effect on the steady-state level of capital stock

$\left(\frac{\partial k^{*}}{\partial \phi}<0 ; \frac{\partial k^{*}}{\partial \theta}<0\right)$. That is, capital accumulation will be lower as a higher fraction of income is smuggled abroad and as a larger fraction of effective labor is spent on capital smuggling.

The model has clear implications, particularly in terms of expected gains associated with curbing capital flight and repatriating capital flight. The increase in domestic saving and tax revenue following repatriation will permit higher rates of physical capital accumulation, which will generate higher economic growth, especially to the extent that revenues from capital flight repatriation are primarily allocated to productive investments. In addition, according to the model, a decline in capital smuggling will result in higher productivity of human capital, which in turn will lead to higher economic growth. In the following section, we use data on the 40 Sub-Saharan countries to illustrate the potential gains from curbing capital flight and enforcing capital flight repatriation. The simulations are informed by the results from econometric estimation of the impact of capital flight on domestic investment as well as the impact of saving on investment.

\section{Data Analysis and Simulations of Potential Gains from Capital Flight Repatriation}

The analysis in this section is based on data for 40 sub-Saharan African countries with updated series of capital flight produced in Ndikumana and Boyce (2008). The analysis is done in three steps: first, we relate the magnitude of capital flight to other forms of external capital inflows to shed light on the relative advantages of curbing capital flight and repatriation of capital flight on the one hand and relying on the conventional sources of external resources, namely FDI, official development aid including debt relief on the other hand. Second, we simulate the expected gains from capital flight repatriation using econometric results on the linkages between capital flight and domestic investment on the one hand, and domestic investment and saving on the other hand.

The idea builds on historical relationships between domestic investment and saving to draw inferences on the gains that would accrue from increases in saving arising from capital flight repatriation. This methodology has the advantage that the simulations take into account the structural relationships between the relevant variable, namely domestic investment, saving, and capital flight.

The third exercise is to simulate potential gains from capital flight repatriation in terms growth through human capital formation. We focus on the impact of capital repatriation on public expenditure on education, that is, we show by how much these expenditures can be increased by taking advantage of capital flight repatriation.

As discussed in the previous section, despite the recent increase in private capital flows to Sub-Saharan Africa, the sub-region still receives a disproportionately small share of the total flows to developing countries. Thus marginalization of the sub-region in the trade arena is compounded by the extremely skewed distribution of flows, making it harder for the sub-region to accelerate its growth rate and achieve sustainable development. 
Furthermore, the marginalization of SSA in the financial and capital markets is exacerbated by the financial hemorrhage in the form of capital flight that the region has experienced over the past decades. The volume of capital flight from SSA exceeds that of the main forms of external capital such as debt, official development aid including debt relief, and private capital flows (Figure 2). The cumulative stock of capital flight from the 40 countries in the sample from 1970 to 2004 exceeds external debt stock (in 2004) by a staggering USD 398.4 billion dollars, making this group of countries clearly a net creditor to the rest of the world [Boyce and Ndikumana (2001) and Ndikumana and Boyce (2003)].

\section{Figure 2: Capital flight, ODA, debt service, and FDI flows to/from 40 SSA countries (billion constant 2004 dollars)}

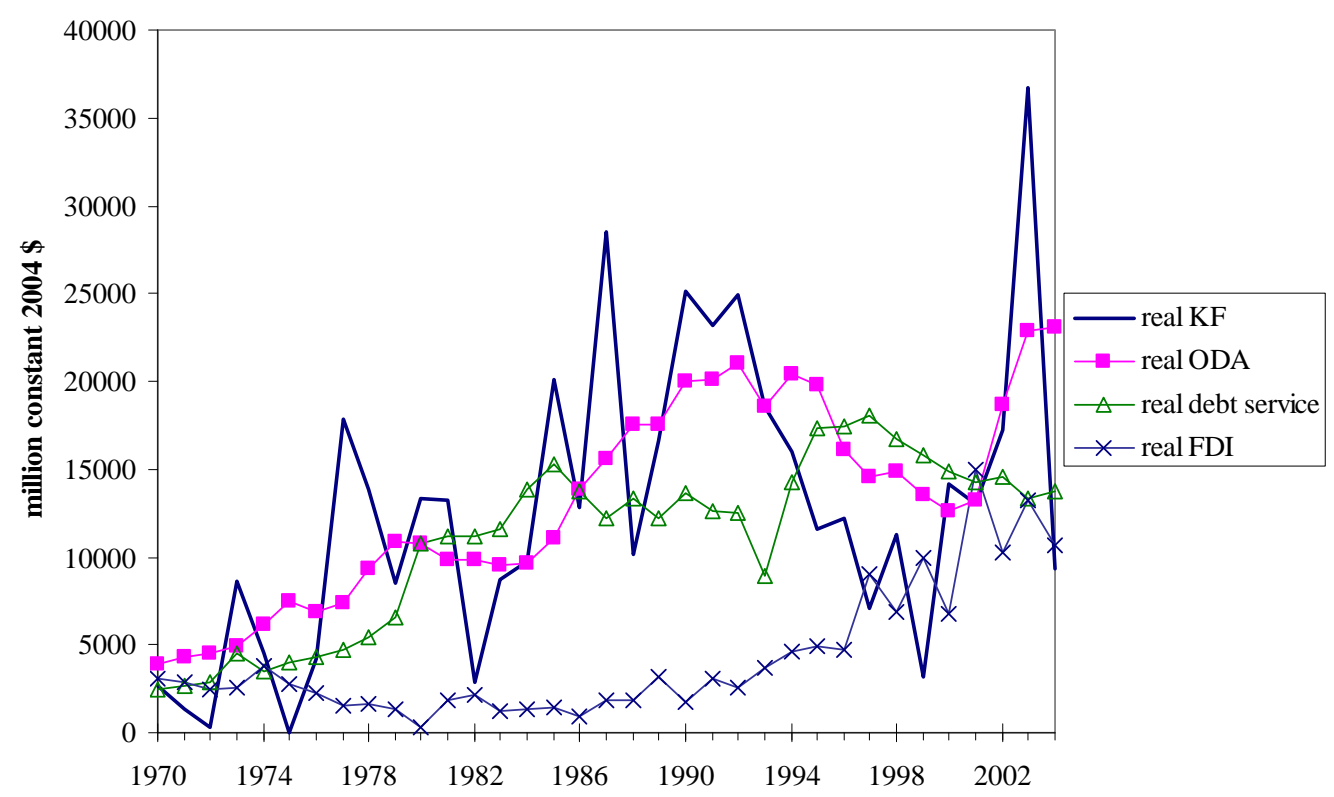

Source: capital flight is from Ndikumana and Boyce (2008); other series from GDF 2006. Note: For capital flight we exclude countries with a negative end-of-period stock of capital flight ${ }^{17}$ (where capital flight reversals outweigh capital flight) to obtain a comparative measure of financial hemorrhage to compare to other forms of inflows and outflows.

Table 2 gives averages per country as well as total values of the flows and stocks for the sample of 40 countries for capital flight and other forms of capital flows. The first column gives the annual averages of capital flight and other flows while the second column contains the stock and the total real values of flows over the 1970-2004 period.

From table 1, it is clear that capital flight dominates other forms of capital flows from and to SSA. The data show that the sub-continent "financed" the rest of the world with capital up to USD 299.9 million per year from capital flight. This compares to an annual average per country of USD 329.1 million per year of official aid, USD 234.9 million of net private capital inflows, USD 147.6 million per year in FDI, and only 41.5 million in debt relief.

\footnotetext{
${ }^{17}$ Countries with end-of-period stock of capital flight are: Benin, Botswana, Comoros, Mali, Niger, Senegal and Togo.
} 
By the end of the period, accumulated capital outflows amounted to USD 606.7 billion compared to a total of $\$ 460.8$ billion of ODA, $\$ 2345.9$ billion of net private inflows and $\$ 58.1$ billion of debt relief. Clearly the amounts of the usual forms of external development financing to SSA pale compared to the volumes of capital that have fled the continent.

Table 1: Capital flight and other flows, annual averages and totals over 1970-2004

\begin{tabular}{l|rr}
\hline & $\begin{array}{c}\text { Annual average flows per country } \\
\text { (million \$) }\end{array}$ & Stocks and total real values (billion \$) \\
\hline Stock of KF & 299.9 & 606.7 \\
Total real KF & & 419.9 \\
Net foreign assets & 329.1 & 398.4 \\
ODA & 41.5 & 460.8 \\
Debt relief & 147.6 & 58.1 \\
FDI & 384.2 & 147.6 \\
Debt service & 96.3 & 384.2 \\
Net transfer on debt & 234.9 & 96.3 \\
Net private inflows & & 234.9 \\
\hline
\end{tabular}

Sources: Capital flight is from Ndikumana and Boyce (2007); other series from Global Development Finance (2006). Note: except for "Stock of capital flight", other flows and totals are in constant 2004 dollars.

At the same time, the sub-continent has also experienced further drainage of resources in the form of payment of external debt. Over the period considered, the 40 countries in the sample paid $\$ 384.2$ billion in debt service. Net transfer on debt amounted to only $\$ 96.3$ billion. In fact, net transfers on debt to this group of countries have trended downward since the early 1980 and have recovered only recently thanks to debt relief. However, further efforts by the international community are needed to increase debt relief while also raising the share of grants and concessional lending in new official resource inflows to SSA.

We examine potential gains from capital flight repatriation in terms of economic growth by focusing on one of the key drivers of economic growth, namely physical capital accumulation. The argument is that capital flight repatriation would boost domestic saving, which in turn would induce higher investment. In addition repatriated capital flight would increase the taxable base, raising government revenue, which would allow the government to increase public investment. This will ultimately boost capital formation, a key driver of long-term growth.

To examine the potential gains from capital flight repatriation we use two sets of empirical relationships. First, we estimate econometrically the effects of capital flight on gross domestic investment, public investment and private investment. We control for real GDP to account for accelerator effects. As the results in Table 2 show, capital flight depresses private investment while it has no discernable effect on public investment.

The results suggest that the negative effects of capital flight on domestic investment operate through private investment more than public investment. One of the reasons is that capital flight, part of which is operated by private actors, reduces the volume of private savings that can be allocated to productive investment. Another reason is that given that environments that are conducive to capital flight are most likely to be characterized by uncertainty, both macroeconomic and political, this implies that private agents will prefer to either defer investment or simply hold alternative assets, including foreign assets 
rather than investing in the country. The savings-liquidity effects are compounded by the uncertainty effects in discouraging domestic private investment.

Table 2: Impact of capital flight on Investment (2-step GMM estimates)

\begin{tabular}{l|rrrr}
\hline & $\begin{array}{c}\text { Total domestic } \\
\text { investment }\end{array}$ & $\begin{array}{c}\text { Private } \\
\text { investment }\end{array}$ & Private investment & Public investment \\
\hline Lagged investment & 0.651 & 0.620 & 0.520 & 0.638 \\
KF & $(0.00)$ & $(0.00)$ & $(0.00)$ & $(0.00)$ \\
GDP growth & -0.007 & -0.026 & -0.021 & 0.0006 \\
& $(0.00)$ & $(0.00)$ & $(0.00)$ & $(0.79)$ \\
Public investment & 0.123 & 0.022 & 0.021 & 0.064 \\
& $(0.00)$ & $(0.00)$ & $(0.01)$ & $(0.00)$ \\
Sargan test & & & 0.014 & \\
& & & $(0.46)$ & \\
$2^{\text {nd } \text { Order }}$ & 37.9 & 27.94 & 29.57 & 30.91 \\
autocorrelation & $(1.00)$ & $(1.00)$ & $(1.00)$ & $(1.00)$ \\
Observations & -1.13 & 0.51 & -0.03 & -0.63 \\
\hline
\end{tabular}

Notes: Regressions in levels and numbers in parentheses are p-values.

We then test econometrically whether and to what extent an increase in domestic savings leads to an increase in domestic investment in this sample of countries. As discussed above, one of the ways in which capital flight depresses investment is by reducing domestic savings. This result is useful in examining potential gains from flight capital repatriation. Our approach is to assume that repatriated capital flight will augment the recipient African country's domestic savings, which will stimulate domestic investment.

To gage this effect of flight capital repatriation on investment, we estimate equations for gross domestic investment, public investment and private investment where investment depends on domestic savings, controlling for GDP (the accelerator effect). The results in Table 3 show that an increase in savings does lead to an increase in private, public, and total domestic investment. As expected, the effect on private investment is larger than that on public investment. According to these results, a 1 percent increase in savings leads to a 0.109 percent increase in domestic investment.

The estimated link between investment and saving as measured by the coefficient of 0.109 may seem smaller than expected. However, in this sample of countries, there are many factors that may explain this small elasticity of investment to savings. First, the weak link between investment and savings is a result of the inefficiencies of the financial systems in these countries that are unable to channel savings into productive investment. In particular, African financial systems are unable to perform their role of maturity transformation, creating a mismatch between the demand of long-term financing and the supply of savings which are mostly kept in the form of liquid and semi-liquid assets. Second, public investment, which is a large fraction of domestic investment is financed partly by aid and therefore not very sensitive to domestic saving. 
Table 3: Impact of savings on investment (GMM 2-step results)

\begin{tabular}{l|rrr}
\hline & $\begin{array}{c}\text { Total domestic } \\
\text { Investment }\end{array}$ & Private investment & Public investment \\
\hline Lagged investment & 0.617 & 0.610 & 0.698 \\
Saving & $(0.00)$ & $(0.0)$ & $(0.00)$ \\
GDP growth & 0.109 & 0.073 & 0.027 \\
& $(0.00)$ & $(0.00)$ & $(0.00)$ \\
Sargan test & 0.115 & 0.011 & 0.089 \\
& $(0.00)$ & $(0.09)$ & $(0.00)$ \\
$2^{\text {nd }}$ order & & & 29.8 \\
autocorrelation & $(1.00)$ & 27.4 & $(1.00)$ \\
Observations & -1.14 & $(1.00)$ & -1.16 \\
& $(0.25)$ & 0.42 & $(0.24)$ \\
& 1125 & $(0.68)$ & 703 \\
\hline
\end{tabular}

Notes: Saving and investment are in \% of GDP and numbers in parentheses are p-values

We will nevertheless use this estimated link between investment and saving to counterfactually illustrate the impact of capital flight on investment. Based on these results, we simulate the effects of capital flight repatriation by assuming that, first the repatriated capital constitutes an increase in domestic saving, and second that the increase in savings will lead to an increase in investment at a rate of 0.109 as estimated in the regression analysis.

Evidently, it is difficult if not impossible to repatriate the totality of capital flight in the short term. Thus we will assume that only a fraction of the stock of capital flight is repatriated, intermediated into the financial system as savings, and eventually allocated to financing investment. Table A1 in the appendix shows for each country the current investment to GDP ratio and the ratios that would result from the repatriation of $25 \%$ of the stock of capital flight as estimated in 2004 . We use average investment and saving to GDP ratios for the period 2000-2004.

The results show clearly that SSA would generate tremendous benefits from capital flight repatriation. If only 25 per cent of the stock of capital flight accumulated up to 2004 was repatriated the average ratio of gross domestic investment to GDP for the sub-continent would increase from the current 18.5 per cent to 29.6 per cent (Table A1). This result is significant on two accounts. First, it implies that through repatriation of only a quarter of capital flight stock, the sub-continent is likely to go from trailing other developing regions to leading in terms of domestic investment (Figure 3). Second, repatriation of this small fraction of capital flight would allow the sub-continent to move very close to the minimum threshold of investment that is conventionally considered to be necessary to achieve the required high growth needed to achieve the millennium development goals. Indeed the UNECA estimated in 1999 that Africa needed to achieve an investment/GDP ratio of 34 per cent in order to record the growth rate of 7 per cent per annum that is needed to halve poverty by 2015 (UNECA 1999).

In general, debates on accelerating growth through domestic investment have focused on mobilization of external private capital flows and increasing domestic resources especially by deepening financial intermediation to increase savings and by raising tax revenues [UNECA (2006), UNCTAD (2007)]. In 
these debates, the issue of capital flight has been overlooked. Yet, without curbing capital flight, African countries will not be able to mobilize enough domestic resources and retain external resources to finance high levels of investment. Most importantly, flight capital and other forms of stolen funds held abroad constitute a source of substantial untapped resources that could contribute to boosting domestic investment. Thus African countries need to design strategies to repatriate flight capital, as an integral part of the national agenda for resource mobilization as a means of accelerating economic growth.

Figure 3: Domestic investment in SSA and other developing regions - with effects of capital flight repatriation

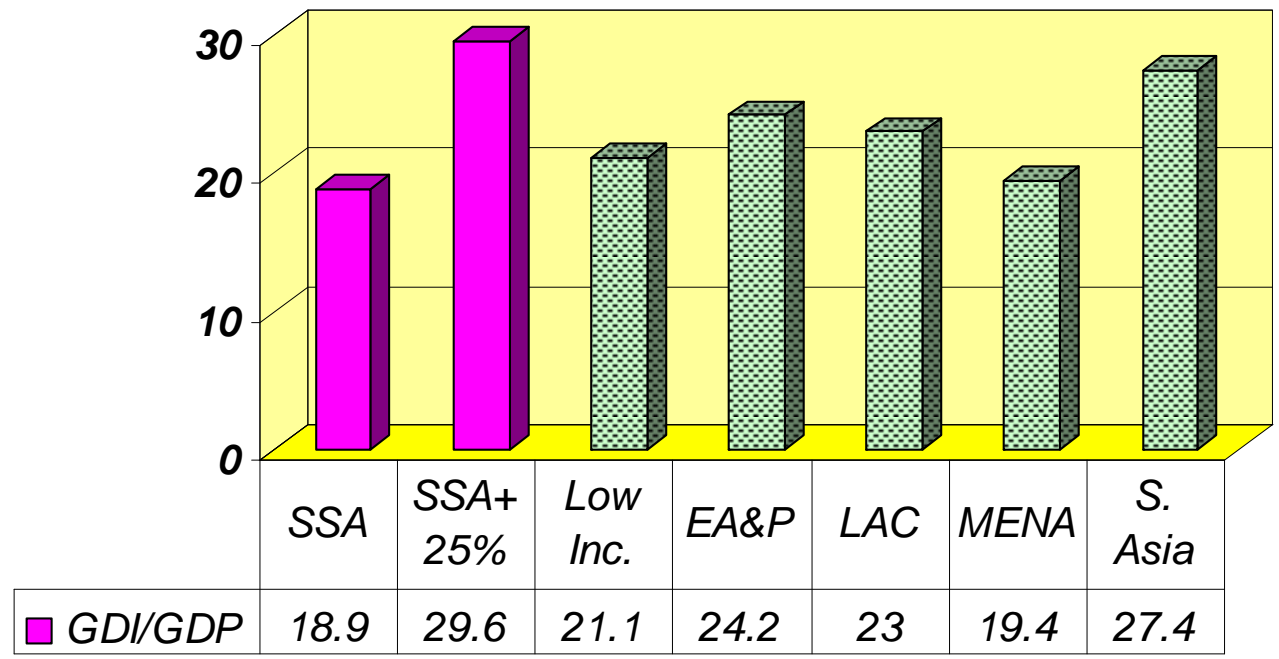

Source: World Bank, World Development Indicators. Note: SSA + 25\% = Gross domestic investment achieved following repatriation of 25 percent of the stock of capital flight.

Another important channel of growth effects of flight capital repatriation is through accelerated human capital accumulation arising from higher funding for education. Given the low levels of government revenue and the myriad competing needs for economic development, funding for education has been low in most African countries. The response has been generally to seek more assistance from international development partners in the form of aid and debt relief. Capital flight repatriation constitutes a major untapped source for boosting expenditures on education in order to bridge the skills gap that constitutes a critical constraint to private sector development and limits international competitiveness for African countries.

To provide an illustration of the potential gains from capital repatriation in terms of human capital investment, we assume that repatriation of capital flight benefits the country by allowing the government to increase expenditure on education. While some of the repatriated capital consists of stolen funds that would go directly into the government budget, a substantial fraction of capital fight is made of private assets earned legally but held abroad illegally in the sense that they were smuggled abroad or/and their owners do not pay tax on the assets. With regard to human capital investment, the repatriation of these private assets will generate benefits through tax revenue, which in turn will be used to finance education. 
Using the data on the countries in the sample covered by this study, and assuming that a moderate 5\% tax is levied on the repatriated capital and used to increase funding for education, we find that the average ratio of education expenditures to GDP would increase from $3.5 \%$ to $4.7 \%$ for the sample (Table A2). For some countries, the ratio would double as a result of increased funding from capital repatriation. This is the case for Burundi, Congo DR, Nigeria, Rwanda, Sao Tome \& Principe, Sierra Leone and Zambia. These substantial increases in education funding would ultimately allow countries to achieve much higher growth rates. Capital flight repatriation as a source of funding for human capital accumulation has clear advantages relative to funding through external assistance as it avoids aid dependence and the associated conditionalities.

\section{Conclusions and Policy Recommendations}

This paper has argued that repatriation of capital flight should take a much more prominent place in the debates about mobilization of resources to increase financing for economic development in African countries. The obvious argument for repatriation is based on a simple moral principle: a large proportion of capital held abroad by Africans was obtained through embezzlement of national resources and fraudulent use of borrowed funds [Ndikumana and Boyce (1998), Fofack (2009)]. ${ }^{18}$ Therefore those funds belong legitimately to the population of African countries and must be repatriated.

The other argument is based on economics principles: instead of continuing to rely on debt-generating resources and other forms of financing that are usually associated with binding direct and indirect commitments, African countries would be much better off tapping the stocks of funds held in Western financial centers in the form of capital flight. This source of financing, unlike aid and debt, does not imply any commitments of future payments to be shouldered by current and future generations. Moreover, a sizable amount of resources can be mobilized in the short run to finance the massive investments critically needed under the "big push" model.

This paper has provided some illustration of the magnitude of potential benefits from capital flight repatriation through domestic investment and education. Using a representative sample of SSA countries, the analysis shows that based on the stock of capital flight as of 2004, and taking into account the empirical linkage between investment and saving, the analysis established that if only 25 percent of the stock of capital flight was repatriated to source countries in SSA, and channeled through the economy as savings, the average investment to GDP ratio in this sample would increase from $18.5 \%$ to $29.6 \%$. This would propel SSA on the top of other developing countries in terms of domestic investment. ${ }^{19}$

These positive effects through domestic investment would eventually launch African countries on a path of higher economic growth, increasing the pace of poverty reduction. This would be achieved while keeping African countries free of the burden associated with external borrowing and other debtgenerating forms of external financing on which African countries have relied in the past. The gains from repatriation also vastly dominate the potential gains from debt relief, the most lauded source of non-debt generating external financing over the recent years.

\footnotetext{
${ }^{18}$ For illustration on this argument, see of the Congo under former president Mobutu, see Ndikumana and Boyce(1998) and Fofack (2009) for the dynamic linkages between capital flight and external debt in Sub-Saharan Africa.

${ }_{19}$ This will go a long way to break the vicious circle of chronically low investment rates, which are believed to have undermined growth prospects during most of the Structural Adjustment era in SSA [Akyuz (2001) and Bayraktar and Fofack (2007)].
} 
For these potential gains to materialize, however, it will be necessary to organize strategies both at the national and international level to induce repatriation of legitimate assets held abroad and impound illegitimate assets stolen from the continent. This implies responsibilities for and will require actions from African governments, western governments, and international banks and financial institutions.

African governments have a huge responsibility in making flight capital repatriation possible. The first area of focus is improvement of the regulatory framework and the overall investment climate in order to attract private assets that were acquired legally and only held abroad for the purpose of maximization of returns on investment and risk minimization. The evidence still indicates that African countries trail behind other countries in terms of the quality of the investment climate [World Bank (2007)]. They score poorly in all areas related to the ease of doing business and exhibit relatively higher transactions costs (UNCTAD 2007). Under these conditions, it will be hard to attract legitimate assets held abroad by Africans. Thus, the strategy for repatriating legitimately acquired assets is an integral part of the national agenda for promoting both domestic and foreign investment.

The second focus of policy is improvement of governance in African countries. Governments in Africa must demonstrate to asset holders that repatriated assets will not be subject to distortionary treatment through distortionary taxation, or even worse, to the risk of embezzlement by corrupt leaders. In this regard, commitment to transparency by the African leadership will be critical in convincing private asset holders to repatriate their wealth back into the continent.

Western governments also have a very important role to play in facilitating repatriation of capital flight. The first area of responsibility is the enforcement of transparency in the banking system. ${ }^{20}$ Historically, African leaders and private asset holders have benefited from the tradition of secrecy that characterizes banking operations in some Western centers whereby depositors of funds are rarely asked to document the origin of their wealth. And even when the asset holders are well known to be corrupt leaders, western banks have often put their profit motives before the principles of honesty and transparency in the dealings with these corrupt leaders. It is the responsibility of Western governments to uproot these practices, which undermine the interests of African populations who are the legitimate claimants on these stolen assets.

Western governments can also play a critical role in the efforts to recover these stolen assets by utilizing their economic and financial intelligence services to uncover deposits of illegally acquired funds especially from African leaders and their private acolytes. Since the beginning of the fight against terrorism in 2001, it has been demonstrated that given adequate political will on the part of Western governments, it is possible to effectively track down illicit transactions. Similarly, albeit belated, the leadership role played by the US government during the Clinton administration was critical for the success in tracking down hidden Nazzi asset. This experience showed that strong political determination is critical to enforce cooperation by Western financial centers in uncovering illicit funds. Such strong political commitment by Western governments will be indispensable for the success of ongoing efforts to repatriate the massive wealth stolen from African countries.

\footnotetext{
${ }^{20}$ Ongoing efforts by the Obama's administration to get rid of bank secrecy laws in the traditional safe haven nations in
} the West is an important step in the right direction. 
In addition to individual countries' initiatives, capital repatriation will require a concerted effort at the international level, especially through the ratification and implementation of specific conventions against fraud, corruption, and money laundering. In this respect, initiatives such as the UN Resolution 55/188 on illegal transfer of assets, the Stolen Asset Recovery initiative, and the International Center for Asset Recovery deserve to be supported and given adequate material, human and political resources to promote transparency in international financial transactions.

As the old saying goes, "it takes two to tango". Thus, in the absence of complicity from Western banks, it would be nearly impossible for corrupt African leaders to channel and hide stolen funds abroad. Banks should not be allowed to hide behind the pretence of client protection to help corrupt leaders in draining the resources that otherwise could have been used to lift millions of Africans out of poverty. Of course, as profit-seeking firms, banks will always have the temptation to evade the law and collude in financial crime. Therefore, it is necessary for Western governments and international financial institutions to design regulatory mechanisms that provide for appropriate and symmetric sanctions to both African smugglers of wealth and their bankers. Thus far when stolen funds have been uncovered, only the African culprits have incurred penalties while their bankers have continued to enjoy impunity. This asymmetric treatment of financial crime undermines efforts aimed at curbing capital flight and recovering stolen funds from the African continent. It also undermines the deterrence capability of programs aimed at curbing illicit outflows of resources from the region.

One possible mechanism for discouraging Western banks from serving as channels of capital smuggling from Africa is to force them to disclose the identity of holders of large balances to the authorities of both the country of incorporation of the bank and the country of origin of the asset holders. This would serve the purpose of not only uncovering stolen funds, but also forcing asset holders to pay taxes on legally acquired assets.

Another mechanism is to include information on transparency of banking practices in the corporate rating of Western banks. Thus, if a bank is discovered to have colluded in acts of financial crimes such as capital smuggling, its rating would be downgraded accordingly. This would have adverse effects on the bank's share prices and eventually its bottom line, which will eventually provide a disincentive for further engaging in colluding with government leaders and private asset holders in smuggling funds from the continent.

Evidently, the critical ingredient in the success of these strategies is strong political will both at the level of African governments and at the international level to enforce transparency in banking and capital account transactions. African countries will have little chance in uncovering and repatriating stolen funds without the support and cooperation of their Western counterparts. Hence, repatriation of capital flight should figure prominently on the agenda for mobilizing domestic resources and boosting international support to accelerate growth and fight against poverty in Africa. 


\section{References:}

Armendariz, de Aghion Beatriz (1991). "Long-term Capital Reflow Under Macroeconomic Stabilization in Latin America." OECD Development Centre Working Paper No. 38

Barrett Devlin (2009). "US sues UBS to get identities of thousands of possible tax cheats", Financial Times.

Bayraktar, Nihal and Hippolyte Fofack (2007). "Specification of Investment Functions in Sub-Saharan Africa." World Bank Policy Research Working Paper No. 4171, The World Bank Group.

Berg, Andy and Zia Qureshi (2005). "The MDGs: Building a Momentum." Finance and Development, 42 (3).

Blejer, Mario and A. Ize (1989). "Adjustment uncertainty, confidence, and growth: Latin America after the debt crisis., Mimeo, IMF.

Boyce, James and Leonce Ndikumana (2007). "New Estimates of Capital Flight from Sub-Saharan African Countries: Linkages with External Borrowing and Policy Options." Mimeo, University of Massachusetts.

Cardoso, E. and R. Dornbusch (1989). "Foreign Private Capital Flows." in H. Chenery and T. Srinivasan (eds), Handbook of Development Economics Vol. II, Amsterdam, North Holland.

Collier, Paul, Anker Hoeffler and Catherine Pattillo (2001). "Flight Capital as a portfolio choice." World Bank Economic Review 20 (3): 335-349.

Dornbusch Rudiger (1991). "Credibility and stabilization." Quarterly Journal of Economics

Dornbusch Rudiger (1991b). "Policies to move from Stabilization to Growth." World Bank Economic Review Supplement, 19-48.

Easterly William (2002). "How did Heavily Indebted Poor Countries Become Heavily Indebted? Reviewing Two Decades of Debt Relief." World Development, 30 (10), 1677-1696.

Edwards Sebastian (1990). "Capital Flows, Foreign Direct Investment, and Debt-Equity-Swaps in Developing Countries.” NBER Working Paper No. 3497, National Bureau of Economic Research.

Fofack Hippolyte (2008). “Technology Trap and Poverty Trap in Sub-Saharan Africa.” World Bank Policy Research Working Paper No. 4582, The World Bank Group.

Fofack Hippolyte (2009). "Determinants of Globalization and Growth Prospects for Sub-Saharan African Countries." World Bank Policy Research Working Paper No. 5019, The World Bank Group.

Fofack Hippolyte (2009). "Causality between External Debt and Capital Flight in Sub-Saharan Africa". Forthcoming World Bank Policy Research Working Paper, The World Bank Group.

Gupta Sanjeev, Catherine Pattillo and Smita Wagh (2007). "Impact of Remittances on Poverty and Financial Development in Sub-Saharan Africa." IMF Working Paper, WP/07/38.

IMF (2007). "Reaping the Benefits of Financial Globalization." International Monetary Fund, Washington DC.

Kasekende Louis (2001). "Capital Account Liberalisation: The Ugandan Experience." Development Policy Review 19 (1), 101-120.

Kose Ayhan, Eswar Prasad, Kenneth Rogoff and Shang-Jin Wei (2006). "Financial Globalization: A Reappraisal.” IMF Working Paper 06/189.

Laban Raul (1991). "Coordination failures and the costly transition from stabilization to growth." Mimeo (MIT, Cambridge). 
Laban Raul (1991). “Capital repatriation and the waiting game.” Economics Letters 37, 249-253.

Laban Raul and Felipe Larrain (1998). "The Return of Private Capital to Chile in the 1990s: Causes, Effects, and Policy Reactions." Development Discussion Paper No. 627, Harvard Institute for International Development, Harvard University.

Larrain Felipe and Andrés Velasco (1990). "Can Swaps Solve the Debt Crisis? Lessons from the Chilean Experience." Princeton Studies in International Finance, No. 69.

Lessard, D. R. and John Williamson (1987). "Capital Flight and the Third World Debt." Institute for International Economics, Washington DC.

Moran Theodore H., Edward M. Graham and Magnus Blomstrom, eds., (2005). "Does Foreign Direct Investment Promote Development?" Institute for International Economics, Washington DC.

Ndikumana, L. and J.K. Boyce, 1998. "Congo's odious debt: external borrowing and capital flight in Zaïre." Development and Change 29 1995-217.

Ndikumana, L. and J.K. Boyce, 2003. "Public debts and private assets: explaining capital flight from subSaharan African Countries.” World Development 31 (1), 107-130.

Ndikumana, L. and J.K. Boyce (2008). "New Estimates of Capital Flight from Sub-Saharan African Countries: Linkages with External Borrowing and Policy Options." PERI/UMass, Working Paper No. 166.

Ozden Caglar and Maurice Schiff eds. (2006). International Migration, Remittances \& the Brain Drain. The International Bank for Reconstruction and Development. The World Bank Group.

Pastor Manuel (1989). "Capital Flight and the Latin American Debt Crisis.” Economic Policy Institute, Washington, DC.

Summers Lawrence H. (2006). "Reflections on Global Account Imbalances and Emerging Markets Reserve Accumulation." Harvard University, Office of the President.

UNCTAD, United Nation Conference on Trade and Development (2007). Economic Development in Africa: Reclaiming Policy Space - Domestic Resource Mobilization and Developmental States. Geneva: United Nations.

UNECA, Economic Commission for Africa (1999). Economic Report on Africa: The Challenges of Poverty Reduction and Sustainability. Addis Ababa: UNECA.

UNECA (2006). Economic Report on Africa 2006: Capital Flows and Development Financing in Africa, Economic Commission for Africa, Addis Ababa, Ethiopia.

UNECA (2007). Economic Report on Africa 2007: Accelerating Africa's development through diversification, Addis Ababa, Ethiopia.

Watts, Robert (2002). "Calling the Swiss to account." Sunday Telegraph (London), November 10, accessed via LexisNexis.

World Bank (2002). "Globalization, Growth and Poverty: Building an Inclusive World Economy." A World Bank Policy Research Report, The World Bank Group.

World Bank (2006). "Global Development Finance: The Development Potential of surging Capital Flows." The World Bank Group, Washington DC.

World Bank (2007a). "Global Development Finance: The Globalization of Corporate Finance in Developing Countries." The World Bank Group, Washington DC.

World Bank (2007b). "Stolen Asset Recovery Initiative: Challenges, Opportunities and Action Plan." The International Bank for Reconstruction and Development, The World Bank Group. 
World Bank (2006). "Debt Relief for the Poorest: An Evaluation Update of the HIPC Initiative." World Bank Independent Evaluation Group. The International Bank for Reconstruction and Development. 
Table A1: Capital flows to developing countries, volumes (billion dollars) and share

\section{ODA}

East Asia \& Pacific

Latin America \&

Caribbean

Middle East \& North

Africa

South Asia

Sub-Saharan Africa

All

DI

East Asia \& Pacific

Latin America \&

Caribbean

Middle East \& North

Africa

South Asia

Sub-Saharan Africa

All

Portfolio flows

East Asia \& Pacific

Latin America \&

Caribbean

Middle East \& North

Africa

South Asia

Sub-Saharan Africa

All
1990

2000

2005

2007

Billion Share Billion Share Billion Share Billion Share Billion

$(\%) \quad \$ \quad(\%) \quad \$ \quad(\%)$

$$
3
$$$$
2.1
$$$$
2.1
$$$$
7.0
$$$$
5
$$$$
25.5
$$

$\begin{array}{rrrrrrrrrr}1.4 & 14.3 \% & 10.3 & 49.4 \% & 44.3 & 32.0 \% & 65.3 & 40.4 \% & 117.4 & 38.0 \% \\ 6.4 & 66.5 \% & 8.3 & 39.7 \% & 79.3 & 57.2 \% & 61.4 & 37.9 \% & 107.2 & 34.7 \% \\ 1.5 & 15.2 \% & 1.0 & 4.9 \% & 4.1 & 3.0 \% & 9.1 & 5.6 \% & 30.5 & 9.9 \% \\ 0.2 & 2.0 \% & 0.3 & 1.4 \% & 4.4 & 3.1 \% & 8.4 & 5.2 \% & 28.9 & 9.3 \% \\ 0.2 & 1.9 \% & 1.0 & 4.6 \% & 6.5 & 4.7 \% & 17.6 & 10.9 \% & 25.3 & 8.2 \% \\ \mathbf{9 . 6} & \mathbf{1 0 0 . 0 \%} & \mathbf{2 0 . 9} & \mathbf{1 0 0 . 0} \% & \mathbf{1 3 8 . 6} & \mathbf{1 0 0 . 0} \% & \mathbf{1 6 1 . 8} & \mathbf{1 0 0 . 0} \% & \mathbf{3 0 9 . 2} & \mathbf{1 0 0 . 0 \%}\end{array}$

$\begin{array}{llllllllll}0.0 & 358.3 \% & 0.4 & 13.3 \% & 6.6 & 51.5 \% & 26.5 & 44.7 \% & 48.6 & 39.1 \%\end{array}$

$\begin{array}{llllllllll}0.0 & 0.0 \% & 2.5 & 74.6 \% & -0.6 & -4.4 \% & 12.5 & 21.1 \% & 28.1 & 22.6 \%\end{array}$

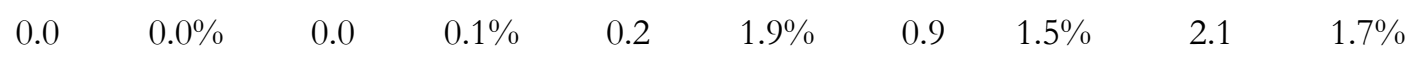

$\begin{array}{llllllllll}0.0 & 0.0 \% & 0.0 & 0.0 \% & 2.4 & 18.6 \% & 12.2 & 20.6 \% & 35.4 & 28.5 \%\end{array}$

$\begin{array}{rrrrrrrrrr}0.0 & 0.0 \% & 0.4 & 11.9 \% & 4.2 & 32.4 \% & 7.2 & 12.1 \% & 10.2 & 8.2 \%\end{array}$

$\begin{array}{llllllllll}0.0 & 100.0 \% & 3.3 & 100.0 \% & 12.8 & 100.0 \% & 59.3 & 100.0 \% & 124.4 & 100.0 \%\end{array}$ 


\section{Net private flows}

East Asia \& Pacific

Latin America \&

Caribbean

Middle East \& North

Africa

South Asia

Sub-Saharan Africa

All

$\begin{array}{rrrrrrrr}7.2 & 17.5 \% & 17.0 & 49.2 \% & 37.8 & 25.0 \% & 107.6 & 41.1 \% \\ 24.9 & 60.5 \% & 13.3 & 38.4 \% & 86.8 & 57.3 \% & 92.4 & 35.3 \% \\ 3.5 & 8.4 \% & 0.6 & 1.8 \% & 5.2 & 3.4 \% & 13.7 & 5.2 \% \\ 1.2 & 3.0 \% & 1.9 & 5.5 \% & 10.7 & 7.0 \% & 21.2 & 8.1 \% \\ 4.4 & 10.7 \% & 1.8 & 5.2 \% & 11.1 & 7.3 \% & 27.1 & 10.3 \% \\ \mathbf{4 1 . 1} & \mathbf{1 0 0 . 0} \% & \mathbf{3 4 . 6} & \mathbf{1 0 0 . 0} \% & \mathbf{1 5 1 . 5} & \mathbf{1 0 0 . 0 \%} & \mathbf{2 6 2 . 0} & \mathbf{1 0 0 . 0 \%}\end{array}$

Source: Global Development Finance 2008. 
Table A2: Estimated impact of capital flight repatriation on domestic investment and education expenditures

\begin{tabular}{|c|c|c|c|c|c|c|}
\hline Country & $\begin{array}{l}\text { Jtock of } \\
\text { capital flight } \\
\text { (million } \\
\text { USD) }\end{array}$ & $\begin{array}{l}\text { Saving/ } \\
\text { GDP } \\
(\%)\end{array}$ & $\begin{array}{l}\text { Investment/ } \\
\operatorname{GDP}(\%)\end{array}$ & $\begin{array}{l}\text { New } \\
\text { investment/ } \\
\text { GDP (\%) }\end{array}$ & $\begin{array}{l}\text { Education } \\
/ \\
G D P\end{array}$ & $\begin{array}{l}\text { New } \\
\text { education/ } \\
\text { GDP (\%) }\end{array}$ \\
\hline Angola & 50950.6 & 24.7 & 12.8 & 16.4 & 3.3 & 6.6 \\
\hline Benin & -7663.9 & 5.5 & 19.0 & 19.0 & 3.1 & 3.1 \\
\hline Botswana & -1086.9 & 39.6 & 25.8 & 25.8 & 4.8 & 4.8 \\
\hline Burkina Faso & 4670.6 & 5.0 & 19.4 & 30.3 & 2.1 & 3.3 \\
\hline Burundi & 2566.6 & & & & 3.0 & 7.9 \\
\hline Cameroon & 27287.7 & 19.1 & 17.2 & 22.0 & 2.5 & 4.6 \\
\hline Cape Verde & 2707.1 & & & & 4.0 & 4.0 \\
\hline Central AR & 2774.1 & 11.4 & 12.6 & 22.2 & 2.8 & 5.4 \\
\hline Chad & 2345.6 & & & & 1.3 & 2.0 \\
\hline Comoros & -168.7 & 0.4 & 11.9 & 11.9 & 4.1 & 4.1 \\
\hline Congo DR & 36737.6 & 4.2 & 8.2 & 37.4 & 1.4 & 8.4 \\
\hline Congo Rep & 17474.8 & 51.9 & 23.6 & 26.5 & 5.2 & 10.2 \\
\hline Cote d'Ivoire & 54000.6 & 20.8 & 10.5 & 16.9 & 5.5 & 9.8 \\
\hline Ethiopia & 22526.0 & 7.4 & 19.2 & 35.2 & 2.3 & 5.1 \\
\hline Gabon & 11997.6 & 43.8 & 26.9 & 28.4 & 2.6 & 4.7 \\
\hline Ghana & 11208.4 & 10.2 & 24.2 & 29.8 & 2.9 & 4.5 \\
\hline Guinea & 1048.9 & 11.1 & 14.6 & 13.8 & 1.9 & 2.2 \\
\hline Kenya & 6369.3 & 11.8 & 14.9 & 15.0 & 5.6 & 6.1 \\
\hline Lesotho & 893.4 & & & & 7.0 & 7.8 \\
\hline Madagascar & 9570.8 & 9.5 & 18.6 & 31.2 & 2.4 & 5.1 \\
\hline Malawi & 3825.4 & & & & 3.1 & 5.6 \\
\hline Mali & -425.4 & 12.2 & 23.6 & 23.6 & 2.9 & 2.9 \\
\hline Mauritania & 4006.0 & & & 58.1 & 4.1 & 7.4 \\
\hline
\end{tabular}




\begin{tabular}{|c|c|c|c|c|c|c|}
\hline Mauritius & 650.1 & 24.7 & 23.5 & 22.2 & 3.6 & 3.6 \\
\hline Mozambique & 14273.4 & 10.6 & 23.5 & 33.8 & 2.7 & 5.7 \\
\hline Niger & -8732.6 & 4.8 & 13.6 & 13.6 & 2.4 & 2.4 \\
\hline Nigeria & 240781.0 & 32.6 & 22.4 & 27.9 & 1.9 & 6.1 \\
\hline $\begin{array}{l}\text { Rwanda } \\
\text { Sao Tome \& }\end{array}$ & 5889.5 & 1.1 & 18.4 & 166.2 & 3.1 & 7.1 \\
\hline Principe & 1059.1 & & & & 3.4 & 24.3 \\
\hline Senegal & -13077.3 & 8.7 & 19.7 & 19.7 & 3.9 & 3.9 \\
\hline Seychelles & 2986.3 & 21.3 & 23.5 & 38.5 & 6.4 & 11.7 \\
\hline Sierra Leone & 7005.4 & & & & 2.0 & 10.1 \\
\hline South Africa & 17492.3 & 20.3 & 16.4 & 14.9 & 5.7 & 5.7 \\
\hline Sudan & 16325.0 & 14.7 & 18.4 & 16.4 & 2.4 & 3.3 \\
\hline Swaziland & 1342.6 & 11.7 & 20.1 & 21.1 & 4.8 & 5.5 \\
\hline Tanzania & 9963.4 & 9.5 & 18.3 & 19.1 & 2.3 & 3.4 \\
\hline Togo & -4064.6 & & & & 4.2 & 4.2 \\
\hline Uganda & 6853.7 & 7.3 & 20.3 & 22.0 & 2.7 & 4.0 \\
\hline Zambia & 19814.3 & 16.0 & 22.8 & 37.8 & 3.2 & 7.8 \\
\hline Zimbabwe & 24556.0 & 8.1 & 10.6 & 30.3 & 5.6 & 12.1 \\
\hline Sample & 606733.7 & 10.4 & 18.5 & 29.6 & 3.5 & 5.0 \\
\hline
\end{tabular}

Sources: capital flight figures from Ndikumana and Boyce (2008); saving, investment and education ratios from WDI 2007. 